\title{
The Effect of Financing and Operational Income on Profit Sharing Return on Mudharabah Deposits for Islamic Commercial Banks
}

\author{
${\text { Faulia Anggeraini }{ }^{*} \text {, Inda Arfa Syera }}^{2}$ \\ ${ }^{1,2}$ Accounting Lecturer, STIE Muhammadiyah Asahan, Indonesia \\ * Corresponding author: \\ Email: aulia86odonk@gmail.com

\begin{abstract}
.
The purpose of this study is to determine the effect of financing and operating income on the return for the results of mudharabah deposits in Islamic commercial banks. The stages of the research method used are the research approach, population and sample, operational definitions, types and sources of data, data collection techniques, data analysis, location and time of research as well as tools and materials. Based on the conclusions found in this study, there is a significant influence of financing variables and operating income variables on the return for the results of Islamic Commercial Bank mudharabah deposits, this is evidenced by the results of research conducted by researchers where the significance value (sig) of 0.001 is smaller than the probability of 0.05 , so it can be concluded that HO is rejected and Ha is accepted, which means that there is an influence of financing and operating income on the return on profit sharing from mudharabah deposits of Islamic
\end{abstract} \\ Commercial Banks.
}

Keywords: Financing, Income, Return

\section{INTRODUCTION}

Sharia Commercial Bank (BUS) is a bank which in its activities carries out business activities in accordance with sharia principles in carrying out payment traffic activities. Sharia Commercial Banks (BUS) are banks that operate with sharia principles and do not rely on interest earning. The relationship between Islamic Commercial Banks (BUS) and their customers is as partners of investors and traders. Sharia Commercial Banks (BUS) function as financial intermediary institutions that carry out their operational activities by collecting funds from the public and then channeling them back to the community through financing. [1]. The basic difference between Islamic bank products and conventional bank products is only in the profit-sharing system and also in the contract agreement [2]. Sharia Bank is a financial institution whose operations collect funds from the public and channel the funds back to the community using a profit-sharing system based on Islamic sharia principles. The products offered are in the form of financing and distribution of funds. The distribution of these funds is usually referred to as sharia financing, one of which uses a murabahah contract.

Financing is used to measure a bank's ability to meet its short-term or maturing obligations. This ratio states how far the bank's ability to repay the withdrawal of funds made by depositors by relying on the financing provided as a source of liquidity. The greater the financing, the income earned will also increase, because income increases automatically profits will also increase. In other words, how far does the provision of financing to customers offset the bank's obligation to immediately fulfill the request of depositors who want to withdraw their money that has been used by the bank to provide financing [3]. The operating expense ratio is used to measure the level and distribution of bank costs in carrying out their operations. Because the main activity of the bank in principle is to act as an intermediary, namely to collect funds and distribute funds. The lower the operational cost ratio, the better the performance of the bank's management, because it is more efficient in using the existing sources of funds in the company [4].

Operating income is an efficiency ratio used to measure the ability of bank management to control operational costs against operating income [5]. Operating revenue is the inflow or other increase in the assets of an entity or the settlement of liabilities (or a combination of both) 
during a period from the delivery or production of goods, the provision of services, or other activities that constitute the entity's ongoing primary or central operations [6].

In BI Circular Letter No. 924/DPBS states that the assessment of the soundness of the bank is influenced by aspects of operational financing, and operating income. For more details, the author will take data on the number of developments in financial statements from Islamic Commercial Banks, especially those related to financing and operating income on the profit sharing of mudharabah deposits of Islamic Commercial Bank .

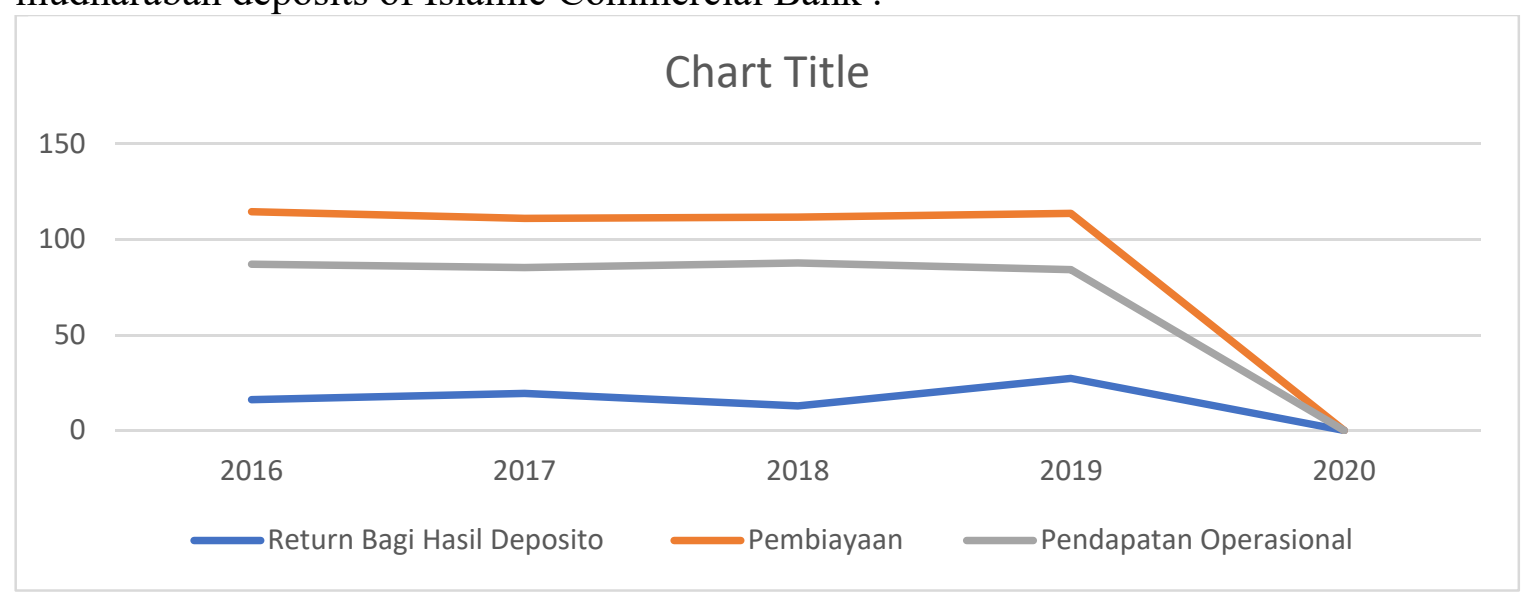

(Sumber: $\underline{w w w . o j k . g o . i d)}$

Figure 1. Financial Statements of Return on Time Deposits, Financing, and Operating Income of Islamic Commercial Banks 2016-2020

Based on the picture above, the ratio of financing and operating income decreased in 2016 and in 2017-2018 experienced an increase. In 2019 financing increased and operating income decreased, and in 2020 financing and operating income decreased. The profit-sharing return fluctuates every year. Associated with the theory, financing is a ratio of credit to third party funds, has a positive influence on changes in profit, meaning that if this ratio shows a high number, the change in profit is also high. Likewise, the increase in operating income shows that the bank's operational performance to generate income has not been efficient which can have an impact on decreasing profitability. This is because the profits obtained are used to cover losses arising from large bank operating costs, but in the financial statement data above, there are several problems that occur in the field, even not in accordance with existing theory.

\section{METHODS}

The approach used in this study is a quantitative approach, because the data measurement uses a numerical scale (numbers). The population in this study is Islamic Banking Statistics (SPS), which includes statistics on Financing, Operational Income, and returns for the results of Islamic Commercial Bank mudharabah deposits from 2016 - 2020 derived from Islamic Banking Statistics (SPS) obtained from the website of the Financial Services Authority. (OJK) with webstie www.ojk.go.id. The sample in this study is Sharia Banking Statistics (SPS) from 2016 to 2020 derived from Sharia Banking Statistics (SPS) obtained from the Financial Services Authority (OJK) website with the website www.ojk.go.id which is published every month. . The analysis of this research is multiple linear regression analysis.

\section{RESULT AND DISCUSSION \\ Kolmogrov-Smirnov Test}

In this study, the results were obtained using a linear regression test on the SPSS 20 application, but before testing the hypothesis in this study, the model must first be tested whether it meets the classical assumptions or not. This test was conducted to determine whether the results of the regression estimation carried out were limited from the symptoms of heteroscedasticity. The data 
normality test process was carried out using the Kolmogorov-Smirnov test, by comparing Z count with a table with the following criteria:

Table 1. Kolmogorov-Smirnov Test

\begin{tabular}{llr}
\hline \multicolumn{3}{c}{ One-Sample Kolmogorov-Smirnov Test } \\
\hline & & \multicolumn{1}{c}{$\begin{array}{c}\text { Unstandardized } \\
\text { Residual }\end{array}$} \\
\hline N & & $\mathbf{5}$ \\
\hline Normal & Mean & $\mathbf{0 E - 7}$ \\
Parameters $\mathbf{a , b}$ & Std. Deviation & $\mathbf{2 , 9 7 9 1 0 6 2 8}$ \\
\hline Most Extreme & Absolute & $\mathbf{3 5 9}$ \\
\cline { 2 - 3 } Differences & Positive & $\mathbf{2 3 7}$ \\
\cline { 2 - 3 } & Negative & $\mathbf{- 3 5 9}$ \\
\hline Kolmogorov-Smirnov Z & $\mathbf{, 8 0 2}$ \\
\hline Asymp. Sig. (2-tailed) & $\mathbf{5 4 0}$ \\
\hline
\end{tabular}

Based on the table One-Smpel Kolmogorov -Smirnov Test above shows a significance value (Asymp.Sig 2-tailed) of 0.540 greater than 0.05 . so it can be concluded that the data is normally distributed. Thus, the assumptions or requirements for normality in the regression model have been met.

\section{Hypothesis testing}

In this study the results obtained using linear regression test on the SPSS 20 application, the results of this linear regression test will display the results, namely:

Tabel 2. Uji R

\begin{tabular}{|l|r|r|r|r|}
\hline \multicolumn{5}{|c|}{ Model Summary } \\
\hline Model & $\mathrm{R}$ & $\begin{array}{c}\mathrm{R} \\
\text { Square }\end{array}$ & $\begin{array}{c}\text { Adjusted R } \\
\text { Square }\end{array}$ & $\begin{array}{c}\text { Std. Error } \\
\text { of the } \\
\text { Estimate }\end{array}$ \\
\hline $\mathbf{1}$ &, $869^{\mathrm{a}}$ &, 756 &, 511 & $\mathbf{4 , 2 1 3 0 9}$ \\
\hline \multicolumn{3}{|l|}{$\begin{array}{l}\text { a. Predictors: (Constant), pendapatanoperasianal, } \\
\text { pembiayaan }\end{array}$} \\
\hline \multicolumn{4}{|l|}{ b. Dependent Variable: returnbagihasil } \\
\hline
\end{tabular}

Based on the table above explains that the value of $\mathrm{R}$ which is a symbol of the value of the correlation coefficient. The correlation value above is $86.9 \%$. The $\mathrm{R}$ square value obtained is 0.756 or $75.6 \%$ which can be concluded that the independent variables X1 (Financing) and X2 (Operational Income) have a contribution effect of $75.6 \%$ on the $\mathrm{Y}$ variable (return for the return on mudharabah deposits) while the remaining $24,4 \% \%$ obtained from other factors not examined in this study.

\section{F Test (Simultaneous)}

The F statistical test basically shows whether all independent or independent variables included in the model have a joint effect on the dependent or dependent variable, as follows:

1. Ha is accepted or $\mathrm{H} 0$ is rejected if Fcount $>$ Ftable at $=5 \%$ and the probability value $<$ level of significant is 0.05 .

2. $\mathrm{Ha}$ is rejected or $\mathrm{H} 0$ is accepted if $\mathrm{F}$ count $>$ Ftable at $=5 \%$ and the probability value $>$ level of significance is 0.05 .

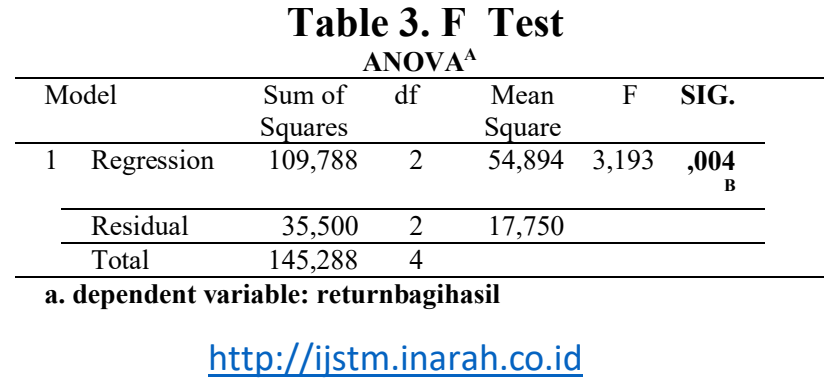


b. predictors: (constant), pendapatanoperasianal, pembiayaan

Based on the table above, it is explained that the $\mathrm{F}_{-}$count test has a value of 8046 with the $\mathrm{F}$ _table value of 3.14, then $\mathrm{F}$ ccount $>\mathrm{F}$ table . while the value of sig $0.004<0.05$, thus the regression equation model based on the research data is significant, meaning that the linear regression model meets the linearity criteria or the variable Financing and Operating Income has an influence on the return for the return on mudharabah deposits of Islamic Commercial Banks

\section{t test (Partial)}

The t-test basically shows how far the influence of one explanatory or independent variable individually in explaining the variation of the dependent variable. The criteria used in accepting or rejecting the (two-way) hypothesis are as follows:

1. $\mathrm{Ha}$ is accepted or $\mathrm{H} 0$ is rejected if $\mathrm{t}$ _count $>\mathrm{t}$-table at $=2.5 \%$ and the probability value $<$ level of significant is 0.05 .

2. Ha is rejected or $\mathrm{H} 0$ is accepted if $\mathrm{t} \_$count $>\mathrm{t}$ table at $=2.5 \%$ and the probability value $>$ level of significant is 0.05

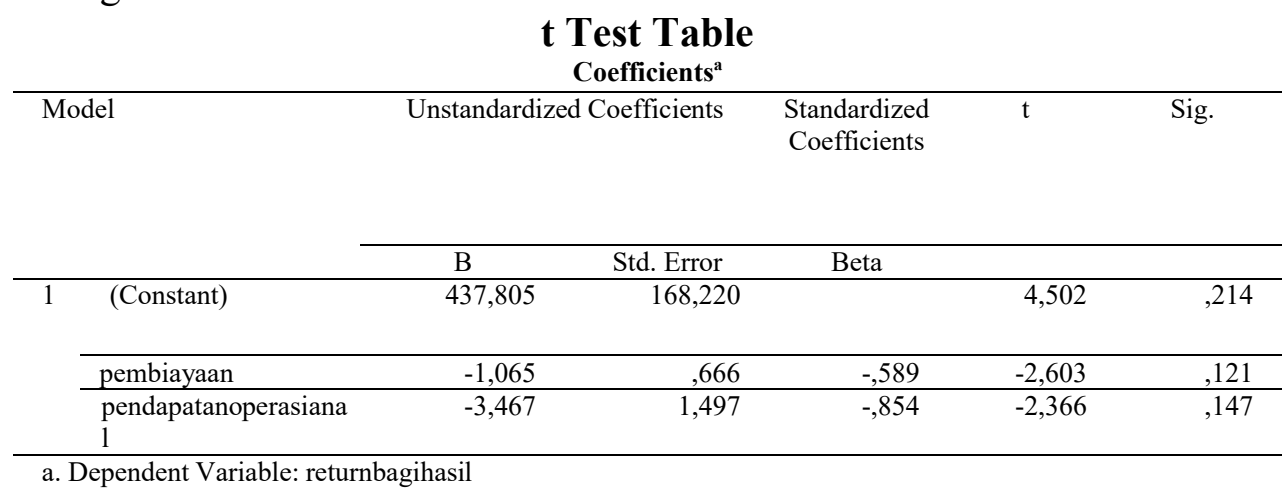

The t-test on Financing (X1) is done by comparing $t$ _count and $t$ table. The value of $t$ count $=2.603$ while $t$ table with a significant level of $=0.10$ obtained a value of 2.35336 (table $t$ statistic). By comparing $\mathrm{t}$ _hitung with $\mathrm{t}$ _tabel, it is obtained that $\mathrm{t}$ _hitung $<\mathrm{t}$ tabel is $\mathrm{t}$. hitung $=2.603<\mathrm{t}$-tabel $=2.35336$ with a significance value of $0.121>0.10$. So it can be concluded that the financing variable has a positive effect on the return for the results of the mudharabah deposits of Islamic Commercial Banks.

The t-test on Operating Income (X2) is done by comparing $t$ count and $t$ table. The value of $\mathrm{t}$ count $=2.366$ while $\mathrm{t}$ table with a significant level of $=0.10$ obtained a value of 2.35336 (table $\mathrm{t}$ statistic). By comparing $t$ _hitung with $t$ tabel, we get $t$ hitung $<\mathrm{t}$ tabel, namely $t$ _hitung $=2,366<$ $\mathrm{t}$ table $=2,35336$ with a significance value of $0.147>0.10$. So it can be concluded that the operating income variable on the return for the results of the mudharabah deposits of Islamic commercial banks

\section{CONCLUSION}

Based on the conclusions found in this study, there is a significant influence of the financing variable and operating income variable on the return for the results of the mudharabah deposit of Islamic commercial banks, this is evidenced by the results of research conducted by researchers where the significance value (sig) of 0.001 is smaller than the probability of 0.05 ., so that it can be concluded that $\mathrm{HO}$ is rejected and $\mathrm{Ha}$ is accepted, which means that "There is an Influence of Financing and Operational Income on the Return on Profit Sharing of Mudharabah Deposits of Islamic Commercial Banks.

\section{ACKNOWLEDGMENTS}

The researcher expresses his deepest gratitude, especially to the Ministry of Education, Culture, Research and Technology which has provided research funding assistance through research grants for novice lecturers 
and researchers. They also give appreciation to all parties, namely members and the academic community of STIE Muhammadiyah Asahan. So that this research can be completed in accordance with the predetermined targets.

\section{REFERENCES:}

[1] OJK, "Statistik Perbankan Syariah (SPS) Dari Tahun 2016 Sampai Dengan Tahun 2019," Jakarta, 2020.

[2] R. A. I. L. Nasib, Keuangan \& Perbankan. Bandung: CV. Sadari, 2019.

[3] J. P. Paranata, "Pengaruh Pembiayaan Mudharabah dan Pembiayaan Musyarakah Terhadap Profitabilitas Bank Umum Syariah di Indonesia," 2013.

[4] K. U. E. A. Y. A. Triyanto, "Faktor-Faktor Yang Mempengaruhi Return Bagi Hasil Deposito Mudharabah (Studi Empiris Pada Bank Umum Syariah Di Indonesia Tahun 2012-2016),” J. Ekon. Dan Perbank. Syariah, vol. 6, no. 1, pp. 63-89, 2019.

[5] S. Septriyana, "Pengaruh Deposito Mudharabahdan Ekuitas Terhadap Pembiayaan Mudharabah (Studi Pada Bank Umum Syariah Periode 2012-2018),” Institut Agama Islam Negeri Ponorogo, 2019.

[6] D. T. R. R. E. D. C. J. Davis, Akuntansi Intermediate, Edisi Kesepuluh, Jilid I, Terjemahan Emil Salim. Jakarta: Erlangga, 2002. 